\title{
Działania papieży oraz Stolicy Apostolskiej na rzecz ochrony osób małoletnich
}

\section{Przystąpienie Stolicy Apostolskiej do Konwencji o Prawach Dziecka przyjętej przez Zgromadzenie Ogólne Narodów Zjednoczonych 20 listopada 1989 roku}

Zakreślony temat wymaga na wstępie doprecyzowania czasowego. Moje rozważania odnoszą się do okresu ostatnich pontyfikatów, tj. do działań trzech papieży: Jana Pawła II, Benedykta XVI i Franciszka.

Zasadniczym argumentem na rzecz takiego ujęcia czasowego tej problematyki jest aktualność zagadnienia ochrony praw małoletnich w ostatnich kilkudziesięciu latach, właściwie począwszy od pontyfikatu papieża Jana Pawła II. Złożył się na to szereg czynników różnej natury, z których najważniejsze to:

- szczególne przywiązanie uwagi do osoby dziecka i jego praw u papieża Jana Pawła II. Wynikało to z osadzenia jego myślenia na personalistycznej koncepcji praw człowieka ze szczególnym akcentowaniem godności człowieka, w tym także godności dziecka jako źródła tych praw,

- rozwijająca się dynamicznie koncepcja praw człowieka na forum międzynarodowym mająca swój wyraz w uchwaleniu 
szeregu konwencji międzynarodowych dotyczących praw i wolności człowieka,

- wprowadzenie przez papieża Jana Pawła II Stolicy Apostolskiej do dyskursu międzynarodowego na forum różnych organizacji w sferze praw człowieka,

- przyjęcie przez ONZ Konwencji o Prawach Dziecka 20 listopada 1989 roku,

- przystąpienie do tej konwencji Stolicy Apostolskiej, mimo iż nie jest ona formalnie pełnoprawnym członkiem ONZ (już w kwietniu 1990 roku).

Podpisanie to miało podwójne znaczenie. Warto ten fakt przypomnieć, albowiem będzie on odgrywał ważną rolę w ocenie postawy Stolicy Apostolskiej w stosunku do wykonywania postanowień konwencji, jakich dokonała Komisja ONZ ds. praw dzieci w swoim raporcie z lutego 2014 roku. Stolica Apostolska poprzez przystąpienie do tej konwencji chciała wyraźnie podkreślić wagę ochrony praw dziecka i swoje zaangażowanie w tej sprawie. Poza tym, co nie jest bez znaczenia, podkreślała rolę ONZ jako światowej organizacji, której jednym z zasadniczych celów jest dbanie o ochronę praw człowieka. Ta rola ONZ w sposób szczególny podkreślona została przez papieża Jana Pawła II już w jego pierwszym wystąpieniu do korpusu dyplomatycznego w styczniu 1979 roku. Jeszcze bardziej znamienne było to, że w swojej pierwszej encyklice Redemptor hominis papież cały passus poświęcił znaczeniu Organizacji Narodów Zjednoczonych. To zaufanie związane było zawsze ze szczególną rolą organizacji w zakresie ochrony praw człowieka. We wspomnianej encyklice papież pisze:

W każdym razie trudno tutaj nie wspomnieć z uznaniem i z głęboką nadzieją na przyszłość o tym wspaniałym wysiłku, jaki podjęto wraz z powołaniem do życia ONZ - o wysiłku zmierzającym do tego, aby określić i ustalić obiektywne i nienaruszalne 
prawa człowieka, zobowiązując się wzajemnie do ich ścisłego przestrzegania ${ }^{1}$.

Z przystąpienia do tej konwencji ONZ wynikało głębokie przekonanie Stolicy Apostolskiej, a zwłaszcza samego papieża, że będzie ona stanowiła efektywną uniwersalną postawę ochrony praw dziecka. Papież Jan Paweł II wskazuje na ważny problem współczesnego świata, jakim jest problem niesłusznie cierpiących dzieci, zwłaszcza tych zmuszanych do pracy w nieludzkich warunkach. W swoim orędziu na Światowy Dzień Pokoju w 1999 roku upomina się o dzieci żołnierzy. Dostrzega głębokie niszczenie ich godności prowadzące do deprawacji ich życia. Mówi:

Czyż można pogodzić się z takim niszczeniem życia, które dopiero zaczyna się rozwijać? Dzieci te, wyszkolone w zabijaniu i często przymuszane do zabijania, z pewnością napotkają ogromne trudności, gdy będą kiedyś chciały włączyć się w życie cywilnego społeczeństwa. Przerywa się ich edukację i nie rozwija ich zdolności do pracy; jakież konsekwencje będzie to miało dla ich przyszłości? Dzieci potrzebują pokoju i mają do niego prawo ${ }^{2}$.

Przejawia także swoją głęboką troskę o młodociane ofiary min i innych środków niszczenia pozostawionych przez wojnę. W swoich wystąpieniach papież Jan Paweł II mówi o szerokich i bardzo różnorodnych zagrożeniach praw dziecka, wynikających zarówno

1 Joannes Paulus PP. II, Litterae apostolicae Redemptor hominis Iesus Christus est centrum universi et historiae, 4.03.1979, „Acta Apostolicae Sedis” [dalej: AAS] 71 (1979), s. 257-324; polska wersja: Jan Paweł II, Redemptor hominis. Encyklika Ojca Świętego Jana Pawła II, Warszawa 1979.

2 Jan Paweł II, Orędzie na XXXII Światowy Dzień Pokoju, www.vatican.va/ holy_father/john_paul_ii/messages/peace/documents/hf_jp-ii_mes_14121998_ xxxii-world-day-for-peace_pl.html (10.01.2015). 
z sytuacji społecznej i ekonomicznej różnych państw, jak i zagrożeń w sferze łamania reguł moralnych. W tym kontekście dostrzega i zwraca uwagę na niebezpieczeństwo i zranienie, jakim jest dla nieletniego wykorzystanie seksualne.

Papież Jan Paweł II, dostrzegając potrzebę zajęcia się w szczególny sposób ochroną praw dzieci, ucieka się do dość nietypowej formy, a mianowicie pisze orędzia i specjalne listy, których adresatami są bezpośrednio dzieci. Tym samym chce je upodmiotowić i zwrócić uwagę świata na godność dzieci, a zarazem na współczesne zagrożenia praw dzieci. I tak w maju 1984 roku kieruje list do dzieci w przeddzień święta dzieci podczas pielgrzymki do Korei Południowej. Papież pisze m.in.:

Głoszę waszą ludzką godność jako dzieci Bożych, stworzonych do tego. By uczestniczyć na zawsze w Bożej miłości. Głoszę wasze prawa, bez względu na to, jak małe lub bezbronne jesteście; [...] Szczególną miłością darzę każde dziecko, które cierpi, które jest samotne, które jest opuszczone, zwłaszcza to, które nie ma nikogo, kto by je kochał i o nie zadbał?

Kolejny list pisze w grudniu 1994 roku, w Roku Rodziny. W kontekście Bożego Narodzenia rozważa kwestie praw dzieci na całym świecie. Upomina się o dzieci nienarodzone, o dzieci wykorzystywane jako tania siła robocza, dzieci z rodzin rozbitych, dzieci wykorzystywane seksualnie.

Nauczanie Jana Pawła II daje podstawy do sformułowania jasnego katalogu praw dzieci. Są to: prawo do życia, a więc prawo do narodzenia się; prawo do wychowania w rodzinie, prawo do ochrony

3 Zob. Jan Pawet II - Papież dzieci. Notatka na stronie internetowej Centrum Jana Pawła II z dnia 31 maja 2013 roku: www.janpawel2.pl/centrumjp2/1045-jan-pawe-ii-papie-dzieci-,Jan Paweł II - Papież dzieci. 
zdrowia, prawo do nauczania religii, prawo do życia w pokoju, prawo do ochrony przed wykorzystaniem zarówno ekonomicznym, jak i moralnym. Prawa te pozostają w pełnej syntonii z prawami zawartymi w Konwencji ONZ o prawach dziecka. Z tego też względu Stolica Apostolska tak szybko, bo kilka miesięcy po uchwaleniu, przystąpiła do konwencji.

\section{Ochrona praw nieletnich w Kościele za pontyfikatu papieża Jana Pawła II}

Kiedy papież Jan Paweł II tak mocno mówi o prawach człowieka i prawach dziecka, jest to czas, kiedy skala zjawiska wykorzystywania seksualnego nieletnich występującego w Kościele nie jest jeszcze dokładnie rozpoznana. Ówczesne myślenie papieża Jana Pawła II o prawach dziecka ma zatem charakter generalny, nie jest jeszcze nacechowane skoncentrowaniem się na problematyce seksualnego wykorzystywania nieletnich. W okresie późniejszym, kiedy problem ten ujawni się z całą siłą, pozytywne działania i zabiegi papieża Jana Pawła II i Stolicy Apostolskiej w ochronie dzieci zostaną całkowicie przykryte ostrą krytyką zjawiska pedofilii w Kościele. Stąd też działania papieża Jana Pawła II i kolejnych papieży w zakresie praw dziecka oceniane będą właściwie jedynie poprzez pryzmat ich zaangażowania się w kwestię walki ze zjawiskiem pedofilii wśród duchownych.

Przypomnieć w tym miejscu należy, że w okresie rozpoczęcia pontyfikatu papieża Jana Pawła II obowiązuje instrukcja zatwierdzona przez Jana XXIII z 16 marca 1962 Crimen sollicitationis ${ }^{4}$, wydana przez ówczesne Święte Oficjum, późniejszą Kongregację

4 Suprema Sacra Congregatio Sancti Officii, Instructio Crimen sollicitationis de modo procedendi in causis sollicitationis, 16.03.1962, Typis Polyglottis Vaticanis 1962 . 
Nauki Wiary. Instrukcja ta zawierała wskazania, jak realizować przepisy Kodeksu prawa kanonicznego z 1917 roku w odniesieniu do osób duchownych oskarżonych o namawianie penitenta do grzechu przeciwko szóstemu przykazaniu.

Papież Jan Paweł II zabiera głos w takim zakresie, w jakim zdobywa wiedzę na temat zjawiska wykorzystywania seksualnego dziecis. Świadczy o tym wydanie przez niego 30 kwietnia 2001 roku listu apostolskiego Sacramentorum sanctitatis tutela ${ }^{6}$. Jest on wydany jeszcze przed tymi wszystkimi tak bardzo nasilonymi atakami medialnymi na Kościól. Papież Jan Paweł II podejmuje zatem inicjatywę. Określa wyraźnie tryb postępowania w sprawach o przestępstwo przeciw szóstemu przykazaniu Dekalogu, popełnione przez duchownego wobec osoby poniżej osiemnastego roku życia. Czyny te popełnione przez kapłanów uważane są przez Kościół za ciężkie przestępstwa na równi z dwoma innymi ciężkimi przestępstwami, których można się dopuścić w stosunku do dwóch sakramentów: przeciw Eucharystii i przeciw świętości spowiedzi. Papież odwołuje się do poprzednich regulacji w tym zakresie, a zwłaszcza do konstytucji apostolskiej Pastor bonus ${ }^{7}$, ogłoszonej 28 czerwca

5 A. Żak, Pozwólcie dzieciom przychodzić do mnie (Mk 10, 14). Odpowiedź Kościoła na nadużycia seksualne wobec dzieci i młodzieży, wystąpienie na konferencji w Gdańsku 28.06.2014, archiwum autorki.

6 Joannes Paulus PP. II, Motu Proprio Sacramentorum sanctitatis tutela, riguardante le norme sui delitti più gravi riservati alla Congregazione per la Dottrina della Fede, 30.04.2011, AAS 93 (2001), s. 737-739, polska wersja: Jan Paweł II, List pasterski motu proprio Sacramentorum sanctitatis tutela,

www.opoka.org.pl/biblioteka/W/WP/jan_pawel_ii/motu/sacramentorum_sanctitatis_30042001.html.

7 Joannes Paulus PP. II, Constitutio apostolica Pastor bonus de Romana Curia, 28 czerwca 1988, AAS 80 (1988), s. 841-912; tekst polski: Jan Paweł II, Konstytucja 
1988 roku, której art. 52 stanowi: „Wykroczenia przeciwko wierze oraz poważne przestępstwa, tak przeciwko obyczajom, jak i te popełnione podczas sprawowania sakramentów, doniesione do Kongregacji Nauki Wiary, muszą być przez nią rozpatrzone, a gdyby zaszła potrzeba, Kongregacja ta powinna przystąpić do określenia lub nałożenia sankcji kanonicznych według norm prawa czy to ogólnego, czy własnego". Zatwierdzone zostały wówczas sądowe kompetencje przysługujące Kongregacji Nauki Wiary jako trybunałowi apostolskiemu. W świetle art. 4 jest to bezpośrednia kompetencja Kongregacji Nauki Wiary, która w takich przypadkach działa jako trybunał apostolski. Czyny te objęte są tajemnicą papieską i nie są rozpatrywane przez miejscowe organa wymiaru sprawiedliwości. To jest jeden z obecnie najbardziej kontrowersyjnych i krytykowanych punktów.

Dokumentem wykonawczym, używając prawniczego języka, w stosunku do powyższego listu Jana Pawła II jest dokument De delictis gravioribus ${ }^{8}$, podpisany 18 maja 2001 roku przez kardynała Josepha Ratzingera, ówczesnego prefekta Kongregacji Nauki Wiary. Jego celem było umożliwienie praktycznego egzekwowania przepisów o najpoważniejszych przestępstwach zawartych w liście Jana Pawła II Sacramentorum sanctitatis tutela. W dokumencie tym mówi wyraźnie o delikcie przeciwko moralności, jakim jest przestępstwo przeciwko szóstemu przykazaniu Dekalogu dokonane przez duchownego z nieletnim poniżej 18 roku życia. Wymienione w tym liście przestępstwa (i tylko wymienione tutaj)

apostolska Pastor bonus o Kurii Rzymskiej, przeł. P. Majer, [w:] Kodeks prawa kanonicznego. Komentarz, red. P Majer, wyd. pol. na podst. wyd. hiszp., Kraków 2011, s. 1397-1465.

8 Congregazione per la Dottrina della Fede, De delictis gravioribus eidem Congregationi pro Doctrina Fidei seservatis, 5.11.2001, AAS 93 (2001), s. 785-788. 
należą do jurysdykcji trybunału apostolskiego Kongregacji Nauki Wiary.

Nie ulega zatem wątpliwości, że Stolica Apostolska nie pozostaje bierna w tych sprawach. Jej działania i działania samego papieża są reakcją na poszerzający się zakres informacji i wiedzy na temat skali zjawiska seksualnego wykorzystywania w Kościele.

Stopniowo pojawiają się nowe fakty dotyczące kościoła w Stanach Zjednoczonych. W tym kontekście papież Jan Paweł II zwołuje spotkanie z kardynałami amerykańskimi w Watykanie 23 kwietnia 2002 roku i mówi o ciężkim grzechu Kościoła, nazywa problem po imieniu: „z powodu wielkiego zła uczynionego przez niektórych kapłanów i zakonników patrzy się na Kościół z nieufnością i wielu czuje się zranionych tym, jak działali przełożeni kościelni”. Kościół nie pomoże społeczeństwu, jeśli tego grzechu w sobie nie przełamie środkami właściwymi dla Kościoła. Jan Paweł II mówił też, że „ludzie muszą wiedzieć, że w kapłaństwie i w życiu zakonnym nie ma miejsca dla kogoś, kto mógłby krzywdzić młodych”. Papież podkreśla też czynniki, które do tej pory wpływały na brak dostatecznej reakcji na te zjawiska: „To prawda, że ogólny brak wiedzy o naturze problemu, a czasami także porady ekspertów klinicznych sprawiały, że biskupi podejmowali decyzje, które w skutkach okazywały się błędne. Teraz opracowujecie bardziej wiarygodne kryteria, które dałyby pewność, iż błędy te już się nie powtórzą"9.

Informacja o skali nadużyć w Kościele trafia do papieża Jana Pawła II już w końcowym okresie jego pontyfikatu. Papież podejmuje

9 John Paul II, Address of John Paul II to the Cardinals of the United States, www.vatican.va/holy_father/john_paul_ii/speeches/2002/april/documents/ hf_jp-ii_spe_20020423_usa-cardinals_en.html, (10.01.2014) polska wersja: Jan Paweł II, Przemówienie do kardynałów i biskupów Kościoła w USA zgromadzonych w Watykanie na nadzwyczajnym spotkaniu, 23.04.2002. 
takie działania, jakie w tym czasie jest w stanie podjąć ze względu na informacje, jakie do niego docierają. George Weigel mówił nawet o pewnej luce informacyjnej pomiędzy Kościołami lokalnymi, zwłaszcza amerykańskim, a wiedzą papieża Jana Pawła II. Papież Jan Paweł II zdaje sobie sprawę, że zakres tego skandalu może zachwiać pozycją Kościoła. Jak zawsze jest w tej sprawie jednoznaczny. Wskazuje na konieczność jasności i jednoznaczności postępowania w sprawie przestępstw seksualnych. „Ludzie muszą wiedzieć, że biskupi i kapłani jednoznacznie opowiadają się po stronie pełni prawdy katolickiej, odnoszącej się do zagadnień moralności seksualnej; prawdy, która jest podstawą odnowy życia kapłanów i biskupów, a także małżeństwa i życia rodzinnego" ${ }^{10}$.

\section{Działania papieża Benedykta XVI na rzecz ochrony praw małoletnich Kościele}

Fala związana ze sprawami przestępstw wobec nieletnich w Kościele z całą siłą uderzy w okresie pontyfikatu papieża Benedykta XVI. Staje on pod naporem lawiny spraw sprzed kilkudziesięciu lat. Jest pod bezustannym atakiem mediów, początkowo w związku z sytuacją w Stanach Zjednoczonych. Wkrótce jednak wybucha gwałtownie tłumiona „kwestia irlandzka”. Niezwykle bolesny jest zwłaszcza zakres tych przestępstw w Kościele irlandzkim. Papież Benedykt jako pełniący do czasu wyboru na konklawe w 2005 roku funkcję prefekta Kongregacji Nauki Wiary podejmuje natychmiastowe działania. W 2006 roku w czasie spotkania z biskupami z Irlandii powiedział wprost, że miały miejsce grzeszne i zbrodnicze czyny. Papież Benedykt przypomniał, że Kościół w Irlandii miał w ostatnich latach do czynienia z „licznymi i strasznymi przypadkami

10 Jan Paweł II, Przemówienie do kardynałów i biskupów Kościoła w USA zgromadzonych w Watykanie na nadzwyczajnym spotkaniu, 23.04.2002. 
nadużyć seksualnych w stosunku do nieletnich” i podkreślił, że „są one tym tragiczniejsze, gdy nadużyć tych dopuszczają się ludzie Kościoła”"

Można powiedzieć, że każdy kolejny rok pontyfikatu papieża Benedykta XVI naznaczony jest zmaganiem się z tą kwestią, narastającą lawinowo. Papież Benedykt stawia temu wyzwaniu czoło i podejmuje kolejne kroki, aby przede wszystkim odzyskać zaufanie ofiar. Media mu jednak nie sprzyjają, nie ma ich wsparcia. Działa samotnie, będąc niesprawiedliwie ocenianym za bezczynność. W centrum swoich działań, wzorem poprzednika, stawiał konieczność ochrony godności każdej osoby. Papież Benedykt wskazał też sposób i metodę postępowania w zmaganiu się z tymi sprawami właśnie z punktu widzenia godności każdej osoby. Podkreśla konsekwentnie, że przede wszystkim trzeba rozpocząć od ustalenia prawdy o tym, co się stało. Tylko stanięcie w prawdzie, a nie ukrywanie spraw pozwoli:

- podjąć niezbędne kroki w celu zapobieżenia ich powtórzeniu się,

- zapewnienia przestrzegania prawa,

- a przede wszystkim niesienia pomocy ofiarom i wszystkim, których dotknęło to groźne przestępstwo.

Mając szerszy wgląd w wiele spraw, Benedykt XVI uznał, że reakcja władz kościelnych, zwłaszcza Kościołów lokalnych, była często nieodpowiednia w imię źle pojmowanego dobra Kościoła. W takiej atmosferze ostrej krytyki działań Stolicy Apostolskiej podejmuje podróż apostolską do Stanów Zjednoczonych w dniach 15-20 kwietnia 2008 roku. Wizyta ta była niezwykle dokładnie przygotowywana właśnie z tego punktu widzenia. Papież Benedykt XVI pięciokrotnie - co powszechnie było podkreślane - odniósł się do

11 Cytat za: G. Polak, K. Tomasik, Benedykt XVI o grzechu Kościoła, http://ekai. pl/dossier/x64056/benedykt-xvi-o-grzechu-kosciola/ (12.01.2015). 
skandali seksualnych z udziałem księży, jakie miały miejsce w USA, wyrażając konieczność zadośćuczynienia ofiarom. Wyraźnie podkreślał swą troskę o jednoznaczne i przejrzyste świadectwo nie tylko oficjalnych przedstawicieli Kościoła, ale i wszystkich wierzących. Podkreślał, że w ostatnich latach Kościół ten przeżywał głęboki kryzys związany z przypadkami molestowania seksualnego nieletnich przez osoby duchowne. Spotkał się też z ofiarami pedofilii, choć spotkanie to nie zostało nagłośnione. Można powiedzieć, że podczas swojego pontyfikatu Benedykt odbywał swoiste pielgrzymki pokutne do różnych państw, przepraszając za grzech pedofilii w Kościele i potępiając to zjawisko.

Słowa wstydu i potępienia nadużyć seksualnych, jakie wygłosił w Stanach Zjednoczonych, powtórzył następnie 19 lipca 2008 roku podczas pielgrzymki z okazji 23. Światowych Dni Młodzieży w Australii. Powiedział wówczas wyraźnie, że ofiary powinny otrzymać współczucie i opiekę, ale podkreślił także dobitnie, że odpowiedzialni za popełnienie tego zła muszą być postawieni przed sądem. To już są wyraźne słowa mówiące o odpowiedzialności prawnej. Z uwagi na uniwersalność tych słów papież nie mógł sprecyzować właściwości sądu. Najważniejsze jest jednak to, że wyraźnie wskazał na konieczność poniesienia odpowiedzialności prawnej. Papież Benedykt XVI zaznaczył, że „bycie księdzem jest nie do pogodzenia z nadużyciami seksualnymi, gdyż zadają one kłam świętości”’.

Niezwykle intensywny w działalności papieża Benedykta XVI był rok $2010^{13}$. Układa się on w szczególne kalendarium różnych

12 Cytat za KAI, Jan Pawet II i Benedykt XVI wobec nadużyć seksualnych duchowieństwa, http://ekai.pl/biblioteka/dokumenty/x1 145/jan-pawel-ii-i-benedykt-xviwobec-naduzyc-seksualnych-duchowienstwa/?print=1 (12.01.2105).

13 Kalendarium jest niezwykle bogate. Wystarczy wybrać wiadomości z niektórych tylko dni aktywności Stolicy Apostolskiej w 2010 roku. Tak np. 9.03., Stolica 
działań i podróży apostolskich papieża Benedykta XVI, których linią przewodnią było mierzenie się Kościoła ze zjawiskiem narastania oskarżeń o nadużycia seksualne. 20 marca 2010 roku papież opublikował List pasterski do katolików Irlandiii ${ }^{14}$. W nim to zapowiada przeprowadzenie wizytacji apostolskiej niektórych irlandzkich diecezji, zakonów i seminariów duchownych. Ojciec święty powołał zespół delegatów papieskich w celu przeprowadzenia wizytacji Irlandii. Wśród wysłanników znajdowali się m.in. emerytowany arcybiskup Westminsteru Cormac Murphy-O'Connor, arcybiskup Bostonu kard. Seán Patrick O’Malley, arcybiskup Toronto Thomas Christopfer Collins, arcybiskup Ottawy Terrence Thomas Prendergast. Każdy z nich dokonywał wizytacji innej diecezji irlandzkiej. Członkami delegacji byli także przedstawiciele watykańskiej Kongregacji ds. Instytutów Życia Zakonnego. Papież zarządził również wizytację seminariów w Irlandii oraz Kolegium Irlandzkiego w Rzymie. To było niezwykłe posunięcie: dokonanie takiej wszechstronnej i na taką skalę lustracji, jaka miała miejsce w irlandzkich zakonach i seminariach zdarza się niezwykle rzadko. Świadczyło to o wadze, jaką papież Benedykt XVI przywiązywał do sprawy oczyszczenia Kościoła z pedofilii.

Zwracając się w liście do Irlandczyków do ofiar nadużyć, papież Benedykt XVI przyznaje wręcz, że doznali oni bolesnej zdrady.

Apostolska - pedofilia to problem społeczny, nie tylko kościelny; Niemcy - okrągły stół o pedofilii; 18.05, Irlandia - kościelny raport o ochronie dzieci; USA - bezpodstawne zarzuty wobec Stolicy Apostolskiej w opinii adwokata watykańskiego.

14 Benedictus PP. XVI, Litterae pastorales ad christifideles catholicos in Hibernia, 19.03.2010, AAS 102 (2010), s. 209-220; polska wersja: List pasterski papieża Benedykta XVI do katolików Irlandii, www.vatican.va/holy_father/benedict_xvi/ letters/2010/documents/hf_benxvi_let_20100319_church-ireland_pl.html (20.10.2014). 
Wyraża ubolewanie, że nikt ich nie wysłuchał ani im nie dowierzał, kiedy zdobywali się na odwagę, by mówić o tym, co się stało. Zwraca zatem uwagę na kluczowe kwestie stanowiące pierwszy krok w pomocy ofierze, które były przez lata zaniedbane, o czym mówią wszystkie ofiary:

- wysłuchanie ofiary oraz

- danie wiary jej zeznaniom.

Sprawców nadużyć papież Benedykt XVI wzywa do odpowiedzenia przed Bogiem, ale kolejny raz powtarza, że także przed właściwymi trybunałami za popełnione czyny. Zauważa, że wyrządzono wielką szkodę nie tylko ofiarom, ale także temu, jak kapłaństwo i życie zakonne jest postrzegane w Irlandii. Ważne jest to, że papież powtarza konsekwentnie o odpowiedzialności także przed właściwymi trybunałami. To jest istotna zmiana w kwestii podejścia do egzekwowania odpowiedzialności.

Papież Benedykt XVI podejmuje także intensywne działania w stosunku do zgromadzenia Legionistów Chrystusa. W Watykanie 30 kwietnia 2010 roku odbyło się spotkanie z biskupami - wizytatorami z pięciu krajów (Stanów Zjednoczonych, Meksyku, Chile, Włoch i Hiszpanii), którzy poinformowali o wynikach wizytacji u Legionistów Chrystusa. Wizytatorzy zostali powołani, kiedy wyszły na jaw nowe fakty świadczące o podwójnym życiu założyciela zgromadzenia o. Marciala Maciela Degollado. Papież już na początku swojego pontyfikatu, w maju 2006 roku, dokonał suspensji o. Maciela, nakazując mu całkowite wycofanie się z życia publicznego. W ciągu ośmiu miesięcy biskupi odwiedzili ponad 120 wspólnot i dzieł zgromadzenia, przedstawiając papieżowi raport z tych wizytacji.

18 kwietnia podczas podróży apostolskiej na Maltę papież Benedykt XVI spotkał się z 8 osobami reprezentującymi ofiary dokonywanych przed laty przez duchownych nadużyć seksualnych. W maju tego samego roku, udając się z pielgrzymką do Portugalii, 
podczas rozmowy z dziennikarzami wypowiedział ważne słowa, stwierdzając m.in., że w tych przypadkach „przebaczenie nie zastępuje wymierzenia sprawiedliwości”. Wymieniając „odpowiedzi, jakich musi udzielić Kościół”, papież wspomniał o pokucie, modlitwie, akceptacji, przebaczeniu, jakich należy udzielić, ale również kolejny raz o potrzebie sprawiedliwości.

W dniach 10-13 czerwca 2010 roku w Rzymie miało miejsce spotkanie sekretarzy generalnych Konferencji Episkopatów Europy. Jednym z tematów były zagadnienia nadużyć seksualnych popełnianych przez duchownych. Uznano za konieczne kontakty między konferencjami episkopatów różnych państw, aby wzmocnić działania Kościoła w tej dziedzinie. Niewątpliwie za owoc tego spotkania można uznać Okólnik do Konferencji Episkopatów w sprawie opracowania „Wytycznych dotyczacych sposobu postępowania w przypadku nadużyć seksualnych popetnionych przez duchownych wobec osób niepetnoletnich" ${ }^{15}$.

Kolejnym ważnym krokiem jest zmiana norm postępowania w przypadku popełnienia najcięższych przestępstw. W oparciu o większą wiedzę dotyczącą rozpoznania tego zjawiska i poszukiwania skuteczniejszych środków walki z nim wprowadzone zostają zmiany do listu apostolskiego papieża Jana Pawła II Sacramentorum sanctitatis tutela $\mathrm{z} 2001$ roku $^{16}$. Nowe normy dotyczące nadużyć seksualnych zawierają postanowienia dotyczące

15 W moim wystąpieniu nie zamierzam odnosić się do sytuacji w Kościołach lokalnych i podejmowanych tam inicjatyw, albowiem kwestia ta należy do innego zakresu tematycznego.

16 Congregazione per la Dottrina della Fede, Modifiche introdotte nelle Normae de gravioribus delictis, 15.07.2010, https://press.vatican.va/content/salastampa/it/bollettino/pubblico/2010/o7/15/o46o/o1048.html\#TESTO\%2o IN\%20LINGUA\%20\%20\%2OITALIANA (20.10.2014). 
przyspieszenia procedur, aby skuteczniej działać w sytuacjach najpilniejszych i najpoważniejszych. Zezwalają one także, aby w Trybunale pracowały osoby świeckie; wydłużają okres przedawnienia w postępowaniu kanonicznym z 10 do 20 lat od osiągnięcia przez ofiarę 18. roku życia; przestępstwa nadużyć wobec osób niepełnosprawnych umysłowo traktują tak samo jak wobec nieletnich. Za przestępstwo uznane zostaje także pornografia pedofilska. Zachowano normę tajności postępowania, aby ochronić godność każdej ze związanych z nim osób.

Podejmowane przez papieża Benedykta XVI działania nie przekonują mediów ani organizacji walczących o prawa osób pokrzywdzonych. Znajduje się on pod nieustannym atakiem. Mówi o tym dość gorzko we wrześniu 2010 roku podczas historycznej wizyty apostolskiej w Wielkiej Brytanii. Stara się uświadomić, jak wielką niesprawiedliwością jest mówienie o nim, że niewiele zrobił w walce z nadużyciami seksualnymi w Kościele. Kolejny raz o wielkich cierpieniach spowodowanych nadużyciami mówił w podczas mszy świętej katedrze westminsterskiej. Tego samego dnia po południu w nuncjaturze apostolskiej papież Benedykt XVI spotkał się z pięcioma ofiarami nadużyć seksualnych. Spotkał się także z grupą pracowników i wolontariuszy odpowiedzialnych za ochronę dzieci w środowiskach kościelnych i uznał za stojący „w tak wyraźnym kontraście do długiej tradycji opieki Kościoła nad dziećmi” fakt, że „doznały one nadużyć i złego traktowania z rąk niektórych księży i zakonników".

Papież Benedykt XVI w wywiadzie rzece z niemieckim dziennikarzem Peterem Seewaldem zatytułowanym Światłość świata przyznaje, że sama sprawa pedofilii nie była dla niego zaskoczeniem, szokiem jednak był jej rozmiar: „Pracując w Kongregacji Nauki Wiary miałem do czynienia z przypadkami z USA; widziałem również, jak narastała sytuacja w Irlandii. W tym całym wielkim nieuporządkowaniu był to jednak niesłychany szok. Widok 
duchowieństwa nagle tak zbrukanego, jak również Kościoła katolickiego w jego wnętrzu, był trudny do zniesienia”"

W lutym 2012 roku na Papieskim Uniwersytecie Gregoriańskim w Rzymie została zorganizowana niezwykle ważna konferencja pod tytułem $W$ kierunku uzdrowienia i odnowy (Verso la guarigione ed il rinnovamento). Formalnie nie była to konferencja organizowana przez Watykan, ale była wyraźnie pod auspicjami Watykanu, albowiem otwarta została przez ówczesnego prefekta Kongregacji ds. Wiary kardynała Williama Josepha Levadę. Znaczenie jej polegało na tym, że po raz pierwszy tak otwarcie w obecności reprezentantów 110 konferencji episkopatów świata, przełożonych zgromadzeń religijnych i innych przywódców religijnych reprezentujących różne kultury otwarcie mówiono o problemach nadużyć seksualnych w Kościele, przedstawiono problemy, zmagania, a także świadectwa osób pokrzywdzonych. Jestem przekonana, że dla wielu było to pierwsze zetknięcie się ze skalą zjawiska. Konferencja o takim zakresie została zorganizowana po raz pierwszy. Niewątpliwie niezwykłą wagę miało świadectwo osobiste ofiary Marie Collins z Irlandii, obecnie będącej w składzie nowej komisji papieża Franciszka.

Ważne były słowa kardynała Williama Josepha Levady podczas otwarcia, który powiedział, że pod światłym kierownictwem niegdysiejszego prefekta Kongregacji Nauki Wiary kard. Ratzingera Stolica Apostolska jest w stanie dać właściwą odpowiedź na zwiększającą się liczbę skarg dotyczącą nadużyć seksualnych przez odpowiednie stosowanie norm prawa kanonicznego, między innymi w stosunku do decyzji biskupów i wyższych przełożonych zakonnych. Wyraził też ważne zdanie, adresowane w dużej mierze

17 P. Seewald, Światłość świata. Papież, Kościót, znaki czasu, przekł. P. Napiwodzki, Kraków 2010. 
do episkopatów lokalnych, że niestety większość tych spraw jest załatwiana dopiero pod wpływem nagłośnień medialnych tych skandalicznych zachowań. Uznał, że w przyszłości konieczne jest bardziej aktywne podejście i angażowanie się lokalnych konferencji episkopatów ${ }^{18}$.

Konferencja Nauki zdecydowanie krytycznie oceniła częste milczenie lokalnych Kościołów w tej sprawie. Nakreśliła też wyraźny kierunek postępowania z takich sprawach, formułując swoiste guidelines:

- nie można tuszować sprawy, dobro dzieci, a nie instytucji na pierwszym planie,

- nie można szukać usprawiedliwienia w tym, że w rodzinach, w innych zawodach i środowiskach procent tego typu zachowań jest większy niż w Kościele,

- nie można szukać usprawiedliwienia w okolicznościach zewnętrznych, takich jak np. rewolucja obyczajowa czy szczególne tradycje panujące w różnych krajach,

- nie można lekceważyć sygnałów ostrzegawczych,

- należy w każdej sytuacji wysłuchać pokrzywdzonego,

- należy odrzucić fałszywą solidarność środowiska19.

Kwestią otwartą, nieporuszoną podczas konferencji pozostała kwestia odpowiedzialności prawnej, jej osadzenia zarówno w prawie kanonicznym, jak i w prawie świeckim. Podkreślano wówczas brak wyraźnych dyrektyw Stolicy Apostolskiej w tej sprawie o charakterze uniwersalnym. I ta kwestia pozostaje pilnym problemem

18 „Tuttavia in numerosi casi la risposta è giunta solamente sulla scia della pubblicazione sui mezzi di comunicazione di massa di notizie relative a comportamenti scandalosi da parte di sacerdoti. Per il futuro appare assai più utile un atteggiamento molto più attivo da parte delle Conferenze Episcopali di tutto il mondo" (z raportu z prac konferencji).

19 Raport z prac konferencji. 
do rozwiązania w najbliższej przyszłości. Rok po konferencji na Papieskim Uniwersytecie Gregoriańskim w lutym 2013 roku papież Benedykt XVI podaje się do dymisji i wybrany zostaje papież Franciszek.

\section{Papież Franciszek i jego wizja przeciwstawiania się zjawisku pedofilii w Kościele}

W powszechnej opinii, zwłaszcza medialnej, Franciszek otwiera nowy rozdział w walce $\mathrm{z}$ pedofilią. Nowy papież jest na pewno bogatszy w wiedzę, a także bogatszy o negatywne doświadczenia, zwłaszcza swojego poprzednika. Ma to, czego brakowało papieżowi Benedyktowi XVI: wsparcie mediów, dlatego ma większe możliwości działania. W dużej mierze jednak podąża drogą swoich poprzedników. Poszukuje natomiast różnych form efektywniejszego przeciwstawienia się temu zjawisku.

Jednym z takich przykładów niewątpliwie jest powołanie wiosną 2014 roku Komisji ds. Ochrony Nieletnich ${ }^{20}$. Komisja, na której czele stanął kardynał Bostonu Seán Patrick O’Halley, składająca się z 17 osób, jest organem podporządkowanym bezpośrednio papieżowi. Jest organem autonomicznym w ramach Stolicy Apostolskiej, działającym na podstawie art. 186 i 190 konstytucji apostolskiej Pastor bonus. Ma osobowość prawną zgodnie z kan. 116 Kodeksu prawa kanonicznego. Nie stanowi części Kongregacji Nauki Wiary ani nie przejmuje jej kompetencji. Nie zajmuje się indywidualnymi przypadkami, zatem nie jest ani swoistym sądem, ani organem ścigania. Komisja w świetle projektu statutu, który to statut zatwierdza papież, jest ciałem doradczym, a jej

20 Informacja prasowa $\mathrm{z}$ 22.03.2014 zamieszczona na stronie internetowej: http://pl.radiovaticana.va/news/2014/o3/22/watykan:_powsta\%C5\%82a_papieska_komisja_ds._ochrony_nieletnich_/pol-783967 (20.10.2014). 
członkowie przedstawiają wyniki prac ojcu świętemu. Głównym celem Komisji jest występowanie z inicjatywami, proponowanie polityki zmierzającej do wzmacniania odpowiedzialności lokalnej Kościoła w ramach Kościoła uniwersalnego za ochronę wszystkich dzieci i narażonych dorosłych (vulnarable adults), w szczególności poprzez wzajemną wymianę „najlepszych praktyk”, programów edukacyjnych, kształceniowych, formacji w odpowiedzi na seksualne wykorzystywanie nieletnich. Komisja zostaje powołana na trzy lata ad experimentum. Główną metodą działania są working groups, które koncentrują się wokół specyficznych tematów. Wstępnie ustalono powołanie kilkunastu grup o różnym zakresie działania, w tym dwóch odrębnych grup dotyczących zagadnień prawnych: jednej dotyczącej propozycji nowych norm w prawie kanonicznym, drugiej dotyczącej przygotowania zarysu guidelines w zakresie odpowiedzialności prawnej w prawie świeckim. Jest to materia niezwykle delikatna i trudna. Dotyka różnych kultur, różnych porządków prawnych, a także tradycji. Wypracowywane propozycje będą musiały uwzględniać całą złożoność kulturową. Wkraczają one w kompetencje państw, stąd nie mogą mieć charakteru wiążącego dla państw, nie mogą być państwom narzucone. Mogą co najwyżej wskazywać pewne kierunki, jeśli uda się takie na drodze konsensusu wypracować.

W lipcu 2014 roku papież spotkał się - po raz pierwszy w Watykanie - z ofiarami przestępstw z kilku państw. Do tej pory spotkania odbywały się podczas podróży apostolskich papieża do różnych krajów. Pierwsze takie spotkanie w Watykanie miało miejsce w Domu św. Marty i z woli papieża Franciszka nie było otwarte dla mediów. Papież w interesie ofiar i ochrony ich godności nie chciał z tego czynić wydarzenia medialnego. Chciał osobiście i szczerze porozmawiać z ofiarami, osobami głęboko zranionymi, u których to zranienie pozostaje właściwie na zawsze - tylko jedni radzą sobie z nim lepiej, inni gorzej. 
Papież chce także rozwiązać problem, który był i nadal pozostaje bardzo bolesny dla Kościoła, a mianowicie ochranianie przez biskupów sprawców grzesznych czynów wobec nieletnich, często w źle pojętym interesie Kościoła. Sprawa odpowiedzialności takich biskupów stale powraca. Kard. Seán Patrick O’Malley, pytany o odpowiedzialność biskupów w sprawach związanych z poważnymi przestępstwami duchownych, stwierdził, że jest to jeden z najważniejszych problemów związanych z walką z przestępstwami tego typu wśród duchownych. Podkreślił, że Kościół musi mieć w tej kwestii jasne zasady działania, a biskupi winni wiedzieć, jak w takich sytuacjach reagowaćn ${ }^{21}$.

Głównym ciałem zajmującym się rozpatrywaniem indywidualnych spraw związanych z pedofilią pozostaje Kongregacja Nauki Wiary. W listopadzie 2014 roku papież Franciszek dokonał pewnych zmian w zakresie jej działania. Powołał Kolegium ds. Rozpatrywania Odwołań, złożone z siedmiu kardynałów i biskupów w Kongregacji Nauki Wiary, które będzie rozpatrywać odwołania od wyroków dla duchowieństwa w sprawach nadużyć seksualnych. Jest ono instancją sesji zwyczajnej tej dykasterii i ma usprawnić postępowanie apelacyjne. Celem tego kroku jest przyśpieszenie procedur związanych z rozpatrywaniem spraw. Przewodniczącego i członków tego kolegium mianuje papież. W przypadku gdy postępowanie dotyczy biskupa, właściwą instancją odwoławczą

21 Arcybiskup Bostonu kard. Sean Patric O’Malley stwierdził, że ojciec święty chciałby jak najszybciej rozwiązać sytuację w diecezji Kansas City w stanie Missouri. Tamtejszy biskup Robert Finn został w roku 2012 sądownie uznany za winnego osłaniania byłego księdza, który we wrześniu 2013 roku został skazany na 50 lat więzienia za wytwarzanie pornografii dziecięcej, http://ekai.pl/wydarzenia/ostatnia_chwila/x83883/papiez-chce-pilnie-zajac-sie-sprawa-biskupa-ktory-oslanialksiedza-winnego-pedofilii/ (10.01.2015). 
pozostaje nadal sesja zwyczajna Kongregacji Nauki Wiary, która przypadki szczególne może przekazać do oceny ojcu świętemu. Również nowo utworzone kolegium może przekazać szczególne przypadki do oceny sesji zwyczajnej tej dykasterii. Do jego obowiązków należy okresowe informowanie sesji zwyczajnej o swojej działalności.

Nie ulega jednak wątpliwości, że działania papieża i Stolicy Apostolskiej są pod stałą obserwacją i krytyką zarówno mediów, jak i różnych organizacji krajowych i międzynarodowych zajmujących się prawami ofiar. Wiele takich krytycznych ocen, zwłaszcza dotyczących zaniechania, niedziałania czy też działania niewłaściwego w źle pojętym interesie Kościoła, było uzasadnionych. Niejednokrotnie jednak ocena tych działań jest spłycona, niewłaściwa, nie bierze bowiem pod uwagę istotowej odrębności Kościoła i Stolicy Apostolskiej od innych organizacji społecznych. Przykłada miary, jakie stosuje się do ocen organizacji rządowych czy pozarządowych. Do takich należy raport Komitetu ONZ ds. Praw Dzieci z lutego 2014 roku, zawierający ostrą krytykę Stolicy Apostolskiej za rzekome ukrywanie przypadków pedofilii wśród duchowieństwa i żądający natychmiastowego ukarania winnych. W ocenie Stolicy Apostolskiej raport Komitetu ONZ wykazuje szczególnie poważny brak zrozumienia jej specyficznej natury. W istocie chodzi o rzeczywistość odmienną od innych państw, a to sprawia, że trudniej jest zrozumieć jej rolę i odpowiedzialność. Uwagi komitetu w wielu kierunkach zdają się wykraczać poza jego kompetencje i ingerować w samo stanowisko moralne i w nauczanie Kościoła katolickiego. Można je określić jako próbę ingerencji w nauczanie Kościoła katolickiego na temat godności osoby ludzkiej i korzystania z wolności religijnej.

Stały obserwator Stolicy Apostolskiej przy ONZ w Genewie abp Silvano Maria Tomasi stwierdził, żew raporcie brakuje właściwej, uaktualnionej perspektywy, uwzględnienia serii wprowadzonych 
zmian dla ochrony dzieci. Dodał też, że Stolica Apostolska chce przestrzegać Konwencji ONZ o prawach dziecka zgodnie z jej postanowieniami. W jej preambule mowa jest o obronie życia i ochronie dzieci nienarodzonych i urodzonych. Komitet natomiast rekomenduje, niezgodnie z tymi postanowieniami, by Stolica Apostolska zmieniła swe zdanie w sprawie aborcji ${ }^{22}$. Już chociażby to uniemożliwia realizowanie uwag komitetu.

Jak podkreślił dyrektor Biura Prasowego Stolicy Apostolskiej Federico Lombardi w nocie dla Radia Watykańskiego z 7 lutego 2014 roku, „Stolica Apostolska zawsze mocno wspierała moralnie Organizację Narodów Zjednoczonych jako miejsce spotkania wszystkich narodów [...] Stolica Apostolska też jako jedna z pierwszych na świecie przystąpiła do Konwencji Praw Dzieci [...] przystąpienie Stolicy Apostolskiej do Konwencji było uzasadnione historycznym zaangażowaniem Kościoła powszechnego i Stolicy Apostolskiej na rzecz dobra dzieci”. Stolica Apostolska - powiedział też mocno sekretarz stanu kard. Pietro Parolin - będzie nadal angażowała się we wdrażanie konwencji oraz w utrzymywanie otwartego, konstruktywnego i zaangażowanego dialogu z przewidzianymi przez nią organami. Będzie dalej zajmowała stanowisko i ogłaszała je, nie unikając autentycznego dialogu, przewidzianych procedur, będąc otwartą na uzasadnioną krytykę²3.

Jestem przekonana, jak to już zaznaczyłam, że kluczowym problemem w dalszych pracach komisji papieskiej i w praktyce będzie wzajemna relacja pomiędzy prawem świeckim a prawem kanonicznym w zakresie odpowiedzialności, różnie rozumiana w różnych kulturach. Wypracowanie jednolitych norm postępowania, chociażby dotyczących mandatory reporting, będzie rodziło trudności.

22 Abp Silviano Maria Tomasi w wypowiedzi dla radia watykańskiego.

23 Federico Lombardi w wypowiedzi dla radia watykańskiego. 
Ale poszukiwanie możliwych do zaakceptowania guidelines postępowania w tym zakresie to jedno z zadań tej nowej komisji.

\section{SUMMARY}

\section{Actions taken by the popes and Apostolic See for protection of the minors}

The paper collects the highlights of the actions taken by the popes: John Paul II, Benedict XVI and Francis, and the organs of the Apostolic See such as the Congregation for the Doctrine of Faith protecting minors against sexual abuse. The main conclusion is that the activities of the Church are full of awareness of the seriousness of the problem and they are meant to prevent such crimes in the future.

Keywords: child, abuse, Apostolic See, John Paul II, Benedict XVI, Francis

Hanna Suchocka, Działania papieży oraz Stolicy Apostolskiej na rzecz ochrony osób małoletnich, [w:] Prawa dziecka: perspektywa Kościoła, red. ks. Piotr Kroczek, Kraków 2015, s. 175-197 (Annales Canonici Monographiae, 3).

DOI: http://dx.doi.org/10.15633/9788374384353.10 